\title{
A New Soft switching Fly Back DC-DC Converter with Minimal Auxiliary Circuit Elements
}

\author{
Majid Delshad*, Abbas Narimani \\ Electrical Department, Khorasgan Branch, Islamic Azad University,Isfahan,Iran \\ *Corresponding Author: delshad@khuisf.ac.ir
}

Copyright (C) 2013 Horizon Research Publishing All rights reserved.

\begin{abstract}
A new soft switching pulse-width-modulated (PWM) fly back dc/dc converter with a simple auxiliary circuit is proposed. By adding this auxiliary circuit to the conventional pulse width modulation isolated fly back converter, all power semiconductor devices are soft switched. Therefore switches turn-on under ZCS condition and turn off under zero current zero voltage switching (ZCZVS) condition and diode operates at zero current switching (ZCS) turn-on and turn-off. In addition, the proposed converter frequency is constant and has no additional current stress in the main switch in comparison with conventional ones. Simulation and experimental results justify the theoretical analysis.
\end{abstract}

Keywords Pulse-width-modulated (PWM), Auxiliary Circuit, Zero Current Zero Voltage Switching (ZCZVS), Fly Back Converter

\section{Introduction}

Extended use of electronic devices in human lives caused improvement and development of electronic equipments. Voltage converters were developed simultaneous to fast development of electronic equipment. These feeding sources that have been designed for providing dc voltage and preparing required energy for electronic equipments, are divided in to two groups of linear and switching in terms of the region of transistor function [10].

Linear power sources have high power losses. These sources have some disadvantages such as using in low voltage (about 40 volts), low efficiency (between 35 to 50\%), large weight and volume (due to large input decreasing transformer and need of large heat meters), but despite of segments function linear region, have advantages as simple design, simple circuits and low output ripple. In sum, these sources are restricted in the region that the amount of energy and efficiency are not important [11].

Transistor in switching sources functions in outage and saturation, so have higher efficiency (68 to 98\%) and other advantages as the better flexibility than linear type, can be used as an additive and subtractive voltage, capacity building in higher voltages, and reduce the size and weight of the circuit (due to increased switching frequency).

These sources have different topologies such as buck, boost, buck boost, forward converters and isolated converters (push pull, half-bridge, full-bridge and Flay Beck) that due to advantages and disadvantages, each of them is used for a certain function. In general, due to the high efficiency, fast response and easy control in this converters in comparison with linear kind, these converters are widely used in industry $[3,7,8,9]$.

Switching converters are divided into two categories. The first group is hard switching due to overlapping of voltage and switch current during switching instance and therefore the switching loss is high. The other type is soft switching converter, in this method; the problems of hard switching can be solved by adding circuit or control procedure. Also in this method switching losses and EMI and RFI noises are reduced. The soft switching converters can be divided into three.

- Zero voltage switching (ZVS)

- Zero current switching (ZCS)

- Zero voltage and zero current switching (ZVZCS)

The switching under ZCZVS condition has better function than the other two methods $[1,2,4,9]$.

Isolated switching converters, have isolation transformer and the another advantage of isolation transformer is adding of various outputs without the need for separate regulator. Also transformer can act as Increasing or decreasing the voltage.

Among switching converters, flyback topologies are more desirable while they are simple. These kind of converters are usually applied in low power applications. Flyback converters as well as electrical isolation have the ability to store energy. Power switch in flyback converter has voltage and current stress due to resonance between leakage inductance of transformer and channel capacitor of switch. Therefore an auxiliary circuit is necessary to absorb the voltage spike and provide soft switching condition for semiconductor devices $[1,3,5,6]$. 


\section{Operation Principle of Proposed Flyback Dc-Dc Converter}

The proposed soft switching PWM flyback converter is shown in Figure 1. As it is seen, the circuit can be divided in two sections. The first section is a conventional flyback converter, which is responsible for power transferred into the output. Therefore, it is composed of an isolated transformer, leakage inductor $\mathrm{L}_{\mathrm{L}}$ (placed in the energy path), magnetizing inductor $\mathrm{L}_{\mathrm{m}}$, diode $\mathrm{D}_{1}$, output capacitor $\mathrm{C}_{0}$, and main switch. The second section is an auxiliary circuit cell to provide soft switching conditions. This section causes reduction of switching loss and electromagnetic interferences by preparing switching condition for semiconductor elements under constant frequency. The cell is composed of only three elements which include the resonant capacitor $\mathrm{C}_{\mathrm{r}}$, resonant inductor $\mathrm{L}_{\mathrm{r}}$ and auxiliary switch $\mathrm{S}_{\mathrm{a}}$.

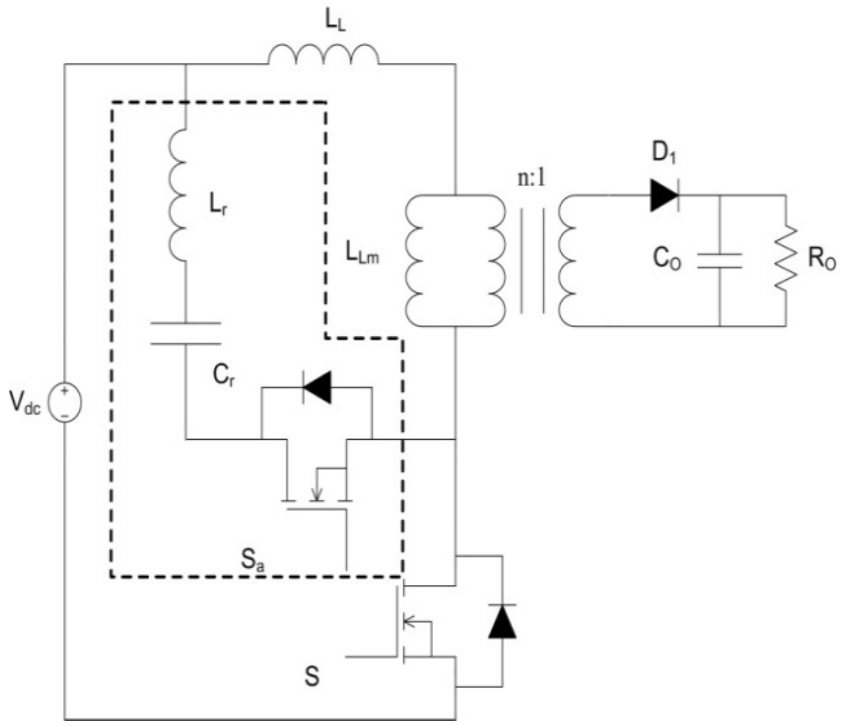

Figure 1. Proposed ZCT flyback converter

- To simplify the analysis, it is assumed that the proposed flyback converter is operated in steady state and the following assumptions are made during one switching cycle.

- All components and devices are ideal.

- The magnetizing inductor $\mathrm{L}_{\mathrm{m}}$ is large enough to assume that the current $\mathrm{I}_{\mathrm{Lm}}$ and the transformer total ampere-turns are considered constant in a switching cycle.

- The output capacitor $\mathrm{C}_{\mathrm{o}}$ is large enough, so the output voltage is constant.

- Input voltage is constant and equals $\mathrm{V}_{\mathrm{in}}$.
Before the first interval, the resonant voltage $\mathrm{V}_{\mathrm{Cr}}$ is positive and equals $\mathrm{V}$, the resonant current $\mathrm{I}_{\mathrm{Lr}}$ equals zero and the main switch is conducting and current it is constant and equals $\mathrm{I}_{\mathrm{Lm}}$.

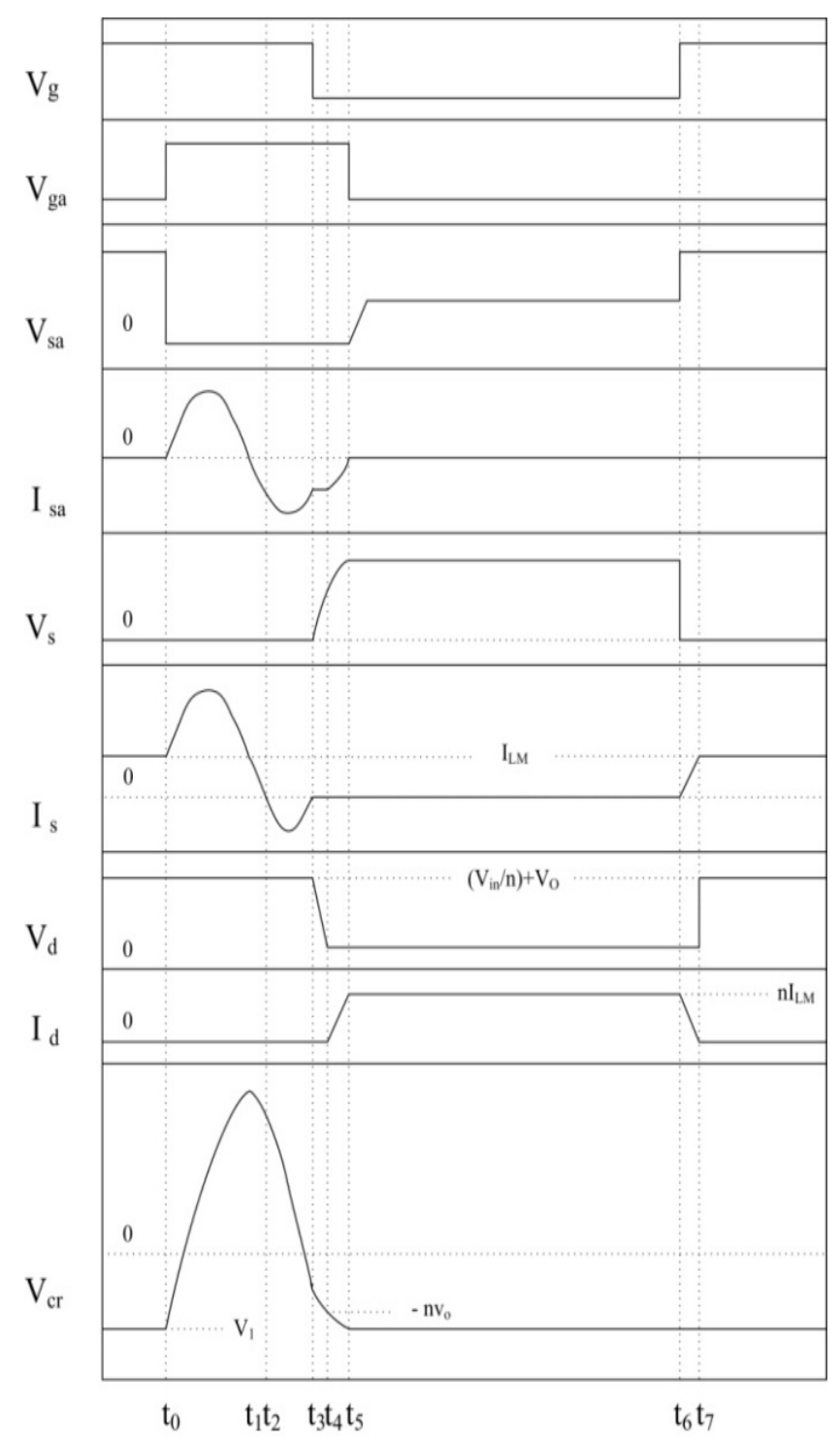

Figure 2. Main theoretical waveforms of the ZCT Flyback converter

Based on these assumptions, circuit operations in one switching cycle can be divided into 8 intervals. In Figure 2. the ideal key waveforms of proposed flyback converter is shown. Also The 8 dynamic equivalent circuits of the proposed flyback converter during one switching period are shown in Figure 3. 


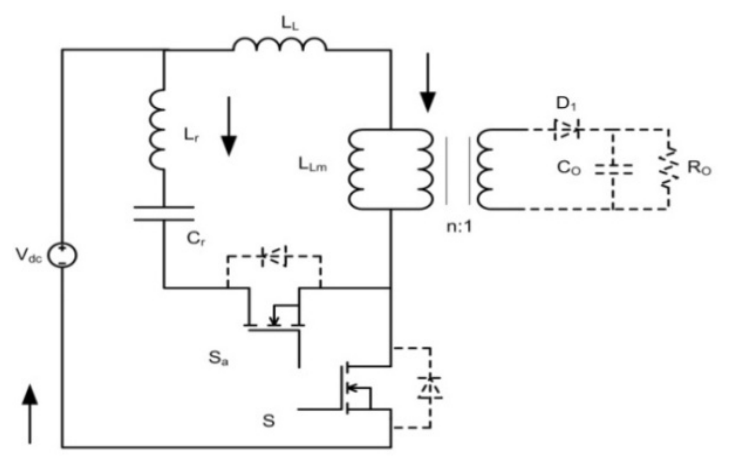

(a)

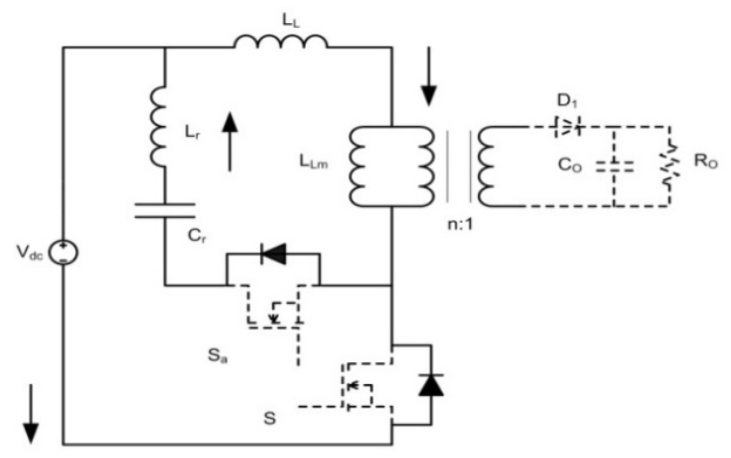

(c)

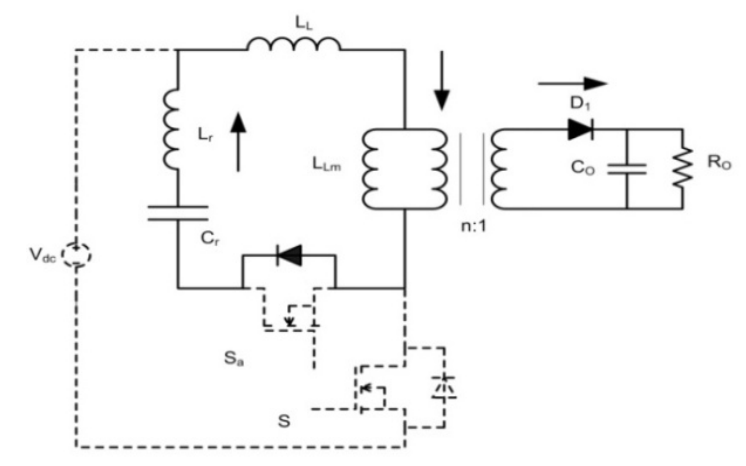

(e)

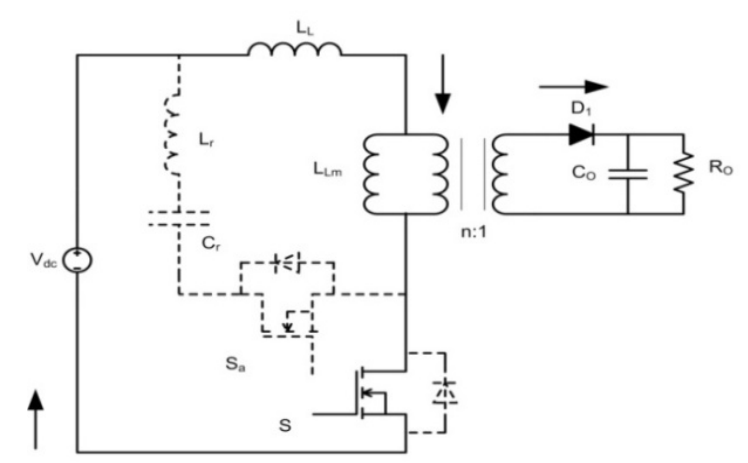

(g)

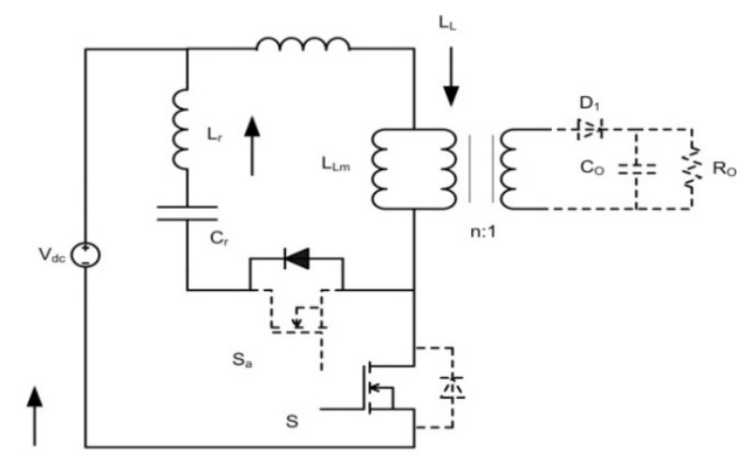

(b)

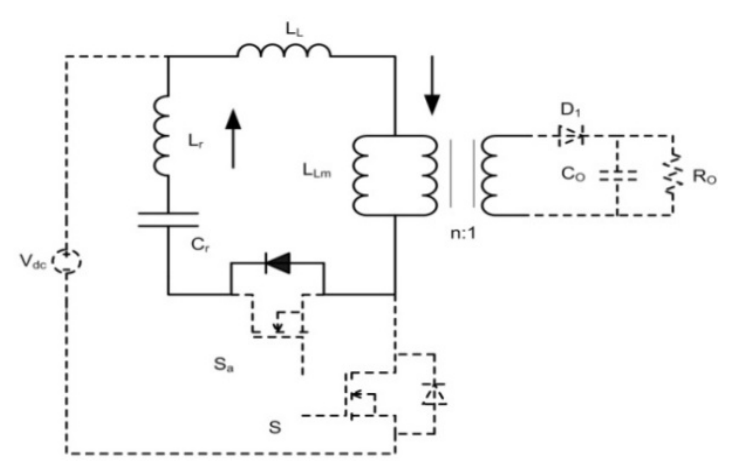

(d)

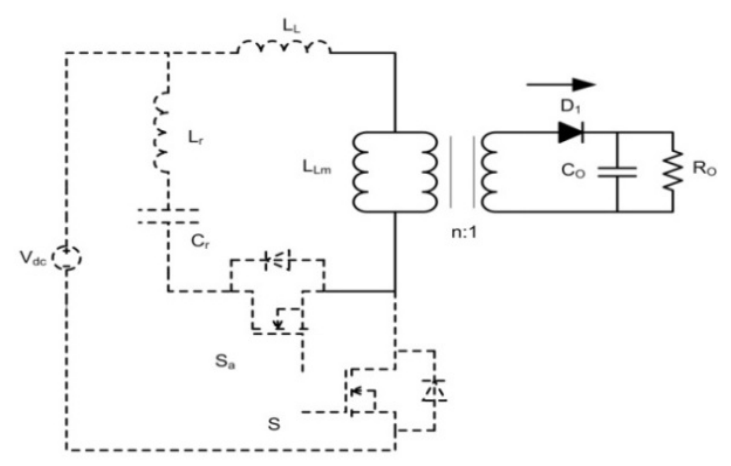

(f)

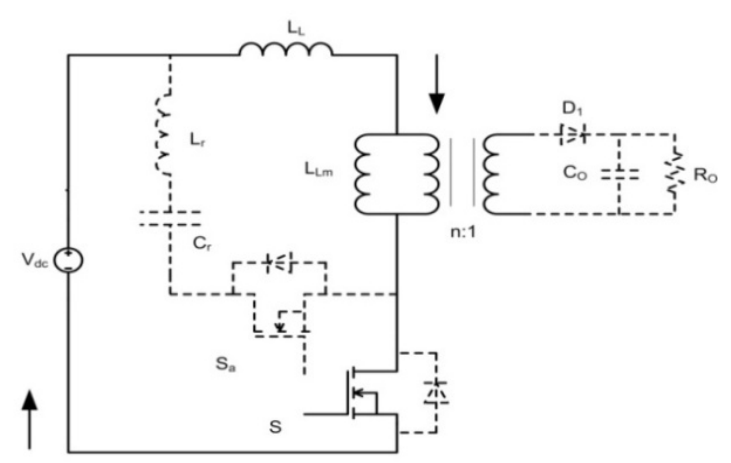

(h)

Figure 3. Equivalent circuit for each operating interval of the ZCT fly back converter. (a) (t0 - t t ). (b) (t1 - t2). (c) (t2 - t3). (d) (t3 - t 4). (e) (t4 - t5). (f) (t5 - t6). (g) (t6 - t7). (h) (t7 - t8) 
INTERVAL $1\left[\mathrm{t}_{0}<\mathrm{t}<\mathrm{t}_{1}\right]$ :

Due to existence inductor resonance $\mathrm{L}_{\mathrm{r}}$, the auxiliary switch under ZCS condition is turned on, and a resonance between $C_{r}$ and $L_{r}$ begins. The auxiliary switch current increases and resonant capacitor $\mathrm{C}_{\mathrm{r}}$ charged. At the end of this interval, auxiliary switch current decrease to zero. The $L_{r}$ current and the $C_{r}$ voltage during this interval are given by

$$
\begin{array}{r}
V_{L r}=\frac{V_{1}-V_{\text {in }}}{Z_{1}} \sin \left(\omega_{1}\left(t-t_{0}\right)\right) \\
V_{C r=} V_{\text {in }}+\left(V_{1}-V_{\text {in }}\right) \cos \left(\omega_{1}\left(t-t_{0}\right)\right)
\end{array}
$$

Where

$$
\begin{gathered}
\omega_{1}=\frac{1}{\sqrt{L_{r} \cdot C_{r}}} \\
Z_{1}=\sqrt{L_{r} / C_{r}}
\end{gathered}
$$

INTERVAL $2\left[\mathrm{t}_{1}<\mathrm{t}<\mathrm{t}_{2}\right]$ :

In this interval the body diode of the auxiliary switch starts to conduct. Inductor and resonant capacitor continue to resonant their and resonant capacitor discharged. At the end off this interval main switch current decrease to zero. The $L_{r}$ current and the $C_{r}$ voltage during this interval are given by

$$
\begin{array}{r}
i_{l_{r}}=\frac{v_{1}-v_{\text {in }}}{z_{1}} \sin \left(w_{1}\left(t-t_{0}\right)\right) \\
V_{C r=}-n V_{o}-Z_{2} I_{L m} \sin \left(\omega_{2}\left(t-t_{3}\right)\right)
\end{array}
$$

INTERVAL $3\left[\mathrm{t}_{2}<\mathrm{t}<\mathrm{t}_{3}\right]$ :

This interval starts when the body diode of the main switch begins to conduct. Inductor and resonant capacitor still continue to resonant and resonant capacitor discharged. At the end of this interval the main switch diode current is zero and main switch is turned off under the ZCZVS condition. Relationship between voltage and current at the time of this interval is similar to the previous interval.

INTERVAL $4\left[\mathrm{t}_{3}<\mathrm{t}<\mathrm{t}_{4}\right]$ :

The resonance current is constant and equal to $\mathrm{I}_{\mathrm{Lm}}$. Therefore, $\mathrm{C}_{\mathrm{r}}$ capacitor is linearly discharged until its voltage reaches $-\mathrm{nVo}$, and at the next interval the diode $\mathrm{D}_{1}$ start to conduct under the ZCS condition. The $\mathrm{C}_{\mathrm{r}}$ voltage at the end of this interval is $-\mathrm{nVo}-\mathrm{ZI}_{\mathrm{Lm}}$.

INTERVAL $5\left[\mathrm{t}_{4}<\mathrm{t}<\mathrm{t}_{5}\right]$ :

Since $\mathrm{D}_{1}$ is conducting and the voltage across the primary side of the transformer is constant and equal $-\mathrm{nVo}$, a resonance starts between $\mathrm{L}_{\mathrm{r}}, \mathrm{L}_{\mathrm{L}}$ and $\mathrm{C}_{\mathrm{r}}$. During this resonance, $\mathrm{D}_{1}$ current increases to $\mathrm{nI}_{\mathrm{Lm}}$, and $\mathrm{S}_{\mathrm{a}}, \mathrm{L}_{\mathrm{r}}$ and $\mathrm{L}_{\mathrm{L}}$ currents decrease to zero. Therefore, auxiliary switch turn off under ZCZV condition.

$$
\begin{aligned}
\omega_{2} & =\frac{1}{\sqrt{\left(L_{r}+C_{r}\right) \cdot C_{r}}} \\
Z_{2}=Z & =\sqrt{\left(L_{r}+L_{L}\right) / C_{r}} \\
\omega_{3} & =\frac{1}{\sqrt{\left(L_{r}+C_{r}\right) \cdot C_{r}}}=\omega_{2}
\end{aligned}
$$

INTERVAL $6\left[\mathrm{t}_{5}<\mathrm{t}<\mathrm{t}_{6}\right]$ :
Diode $\mathrm{D}_{1}$ is still conducting the constant current. During this interval the energy stored in magnetizing inductance $\mathrm{L}_{\mathrm{m}}$ continuously supplies the output and the converter behaves like a conventional flyback converter.

INTERVAL $7\left[\mathrm{t}_{7}<\mathrm{t}<\mathrm{t}_{8}\right]$ :

Due to the existence transformer leakage inductance, the main switch is turned on under the ZCS condition. During this interval, the main switch current is linearly increases to $I_{L m}$ and subsequently $D_{1}$ current is linearly decreases to zero. Therefore $\mathrm{D}_{1}$ turns off under ZCS condition. The main switch current during this interval is given by

$$
I_{S}=I_{L m}+\frac{V_{\text {in }}-\left(-n V_{o}+Z_{2} I_{L m}\right)}{Z_{4}} \sin \left(\omega_{4}\left(t-t_{7}\right)\right)
$$

Where

$$
\begin{gathered}
\omega_{4}=\frac{1}{\sqrt{L_{r} \cdot C_{r}}}=\omega_{1} \\
Z_{4}=\sqrt{L_{r} / C_{r}}=Z_{1}
\end{gathered}
$$

INTERVAL $8\left[\mathrm{t}_{8}<\mathrm{t}<\mathrm{t}_{9}\right]$ :

The main switch is on and the energy is stored in $\mathrm{L}_{\mathrm{m}}$. Therefore, converter behaves like a conventional flyback converter.

\section{Simulation and Experimental Results}

In this section a prototype of the proposed flyback converter operating at $100 \mathrm{KHz}$ is implemented. The converter voltage input is $100 \mathrm{~V}$ and the output voltage is $25 \mathrm{~V}$. The specifications of proposed flyback converter are introduced in Table 1. Simulation and measured waveform of voltage and current of the main switch are shown in Figure 4 and Figure 5 respectively. Simulation and measured waveform of voltage and current of the auxiliary switch are shown in Figure 6 and Figure 7 respectively.

Table 1. The specifications of proposed flyback converter

\begin{tabular}{|c|c|c|}
\hline Component & Prototype & Cost \\
\hline Main switch & IRF840 & \\
\hline Auxiliary switch & IRF840 & \\
\hline leakage inductor & $\mathrm{L}_{l}$ & $7 \mu \mathrm{F}$ \\
\hline Resonant inductor & $\mathrm{L}_{\mathrm{r}}$ & $10 \mu \mathrm{F}$ \\
\hline Resonant capacitor & $\mathrm{C}_{\mathrm{r}}$ & $15 \mathrm{nF}$ \\
\hline Output capacitor & $\mathrm{C}_{\mathrm{o}}$ & $15 \mu \mathrm{F}$ \\
\hline Diodes & MUR860 & \\
\hline
\end{tabular}

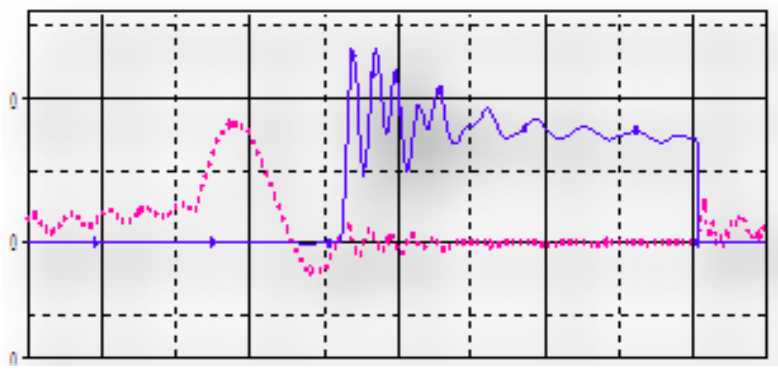

Figure 4. The waveform of voltage and current (dashed) of main switch $(50 \mathrm{~V} / \mathrm{div}$ or $2.5 \mathrm{~A} / \mathrm{div}$, Time scale: $1 \mu \mathrm{s} / \mathrm{div}$ 

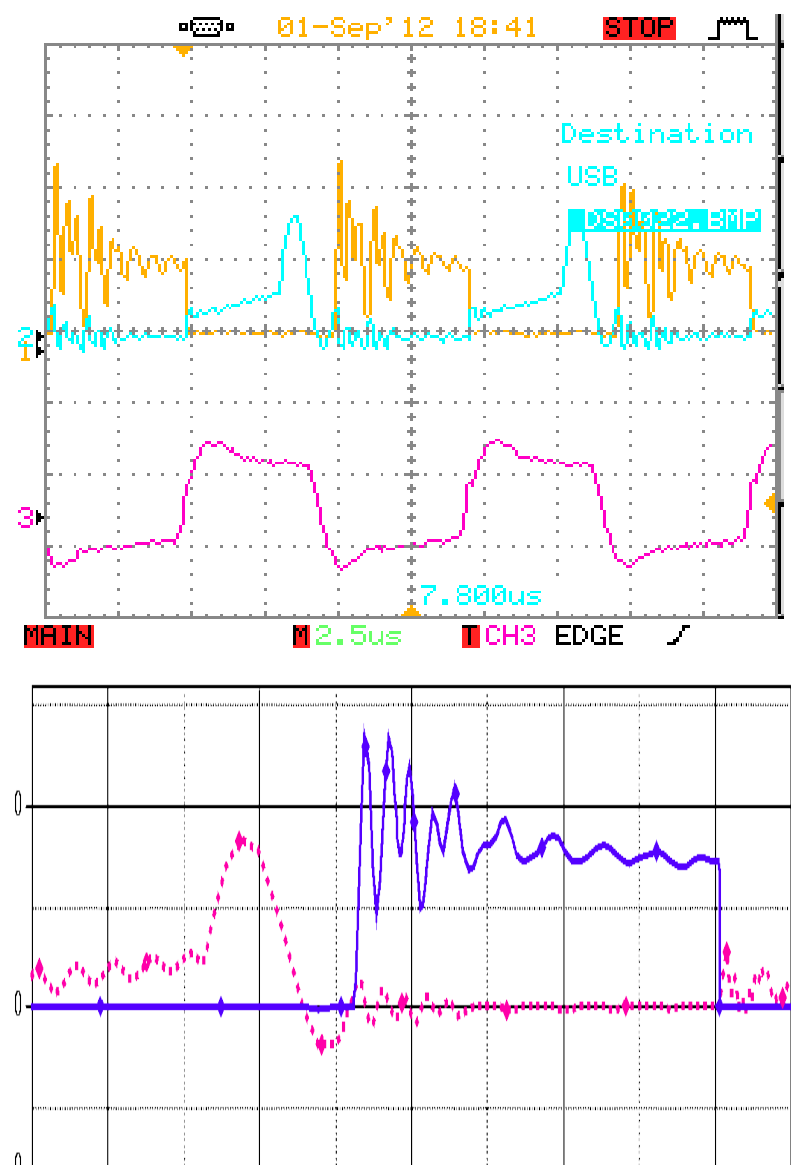

Figure 5. The waveform of voltage and current of main switch $(50 \mathrm{~V} / \mathrm{div}$ or $2.5 \mathrm{~A} / \mathrm{div}$, Time scale: $2.5 \mu \mathrm{s} / \mathrm{div})$

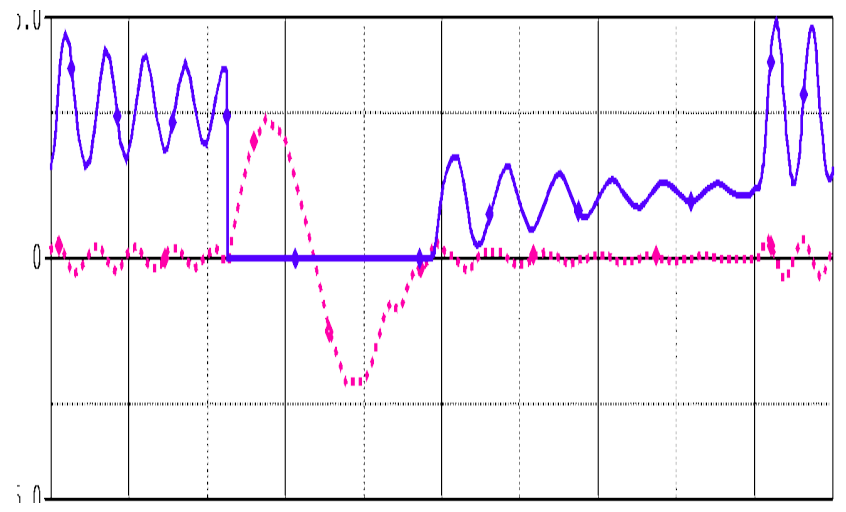

Figure 6. The waveform of voltage and current (dashed) of auxiliary $\operatorname{switch}(50 \mathrm{~V} / \mathrm{div}$ or $2.5 \mathrm{~A} / \mathrm{div}$, Time scale: $1 \mu \mathrm{s} / \mathrm{div})$

\section{Conclusions}

In this paper, a simple auxiliary circuit with minimum elements for flyback converter has been proposed. This auxiliary circuit provides ZCS condition for switches turn on instant and ZVZCS condition for switches turn off instant. So the current stress on switches is reduced and the energy is transferred to the output. But there is a low voltage stress on the switch, which this stress is a characteristic of flyback

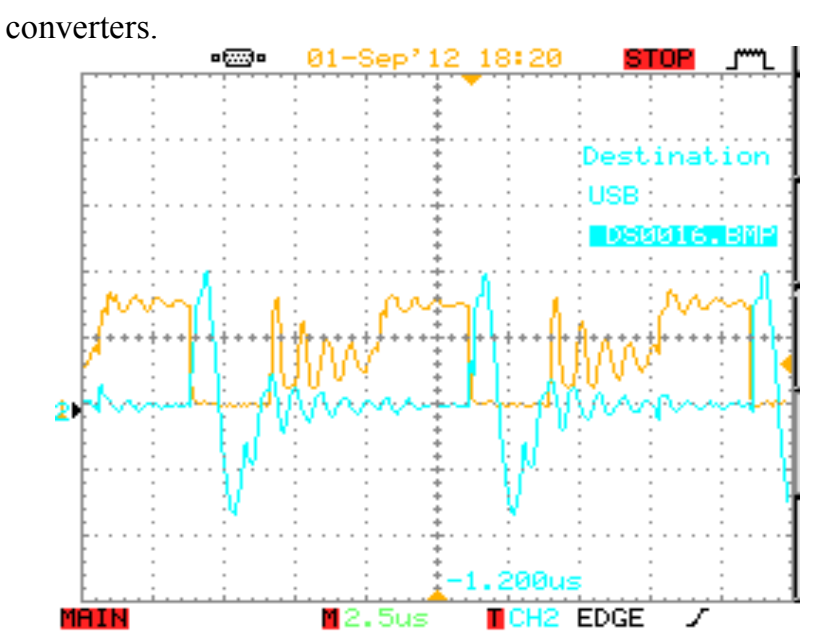

Figure 7. The waveform of voltage and current of auxiliary switch $(50 \mathrm{~V} / \mathrm{div}$ or $1 \mathrm{~A} / \mathrm{div}$, Time scale: $2.5 \mu \mathrm{s} / \mathrm{div}$

\section{REFERENCES}

[1] D. M. Brllur and M. K. Kazimierczuk, "Review of zero current switching fly back pwm dc-dc convwrters, "Wiley, 2008

[2] G. Hua, E. X. Yang, Y. Jiang and F. C. Lee, "Zero current transition pwm converter," IEEE Transactions power electronics, vol. 9, no. 6, pp. 601-606, Mar. 1994.

[3] M. Wang, "A novel zcs pwm flyback converter with a simple zcs pwm commutation cell," IEEE Transactions industrial electronics, vol. 55, no. 2, pp. 749-757, Feb. 2008.

[4] B. R. Lin and F. Y. Hsieh, "Soft switching zeta-flyback converter with a buck boost type of active clamp," IEEE Transactions industrial electronics, vol. 54, no. 5, pp. 2813-2822, Oct. 2007.

[5] H. C. H. Chung, S. Y. R. Hui and W. H. Wang, "A zero current switching pwm flyback converter with a simple auxiliary switch," IEEE Transactions power electronics, vol. 14, no. 2, pp. 329-342, Mar. 1999.

[6] H. Chung, S. Y. R. Hui and W. H. Wang, "AN isolated soft switched flyback converter with low voltage stress," Power electronics specialists conference, pp. 1417-1423, Jun. 1997.

[7] E. Adib and H. Farzaneh fard, "Family of soft- switching pwm converters with current sharing in switches," IEEE Transactions on power electronics, vol. 24, no. 84, pp. 979-985, April. 2009.

[8] E. Adib and H. Farzaneh fard, "Family of zero current transition pwm converters," IEEE Transactions industrial electronics, vol. 55, no. 8, pp. 3055-3063, Aug. 2008.

[9] E. Adib and H. Farzaneh fard, "Family of zero current zero voltage transition pwm converters," IET power electron, vol. 1, no. 2, pp. 214-223, 2008.

[10] Brown, m. Power Supply Cookbook, 2nd ed, p. cm, 2001

[11] Preeman. A, Billings. K, morey. T, switching Power Supply Design, 3nd ed, Mc Grawhill, 2009 